\title{
Local Government Reform in Malaysia
}

\section{Malcolm Norris}

It is common practice in the study of comparative local government to treat certain systems as prototypes, from which other systems derive their structure and diverge on account of local conditions or the peculiarities of national decentralisation. British and French precedents have long held a prominent place, justifiably on grounds of their influence through colonial experiment and continuing interest to independent states. Other systems have more recently attracted attention in developing countries, such as those of American and Irish management, and that of Yugoslavia as an Eastern European type, separable from the highly integrated structure of national communist governments. These references afford an attractive basis for relating similarities and contrasts, and identifying potential areas of difficulty and effective responses. The close reference of the Malaysian Royal Commission's recommendations in 1968 (Government Printer, 1970) to those of the Maud Committee in England are a case in point. It nevertheless remains a fact that the models that have tended to attain prominence have on the whole evolved under conditions very different from those prevailing in the Third World, tending to make their 'lessons' of controversial if not of a merely hypothetical value!

In view of such limitations it would seem advantageous to focus greater attention on the experience of states attaining independence within the last 20 years, and particularly on those which have chosen to emphasise the importance of their local government structure, frequently following a period of rejection of what was perceived as part of their colonial legacy. The success of their measures is in most respects too early to appraise. Their approach and changes of emphasis are, in contrast, aspects of considerable current relevance, more comprehensible and hence useful to others seeking forms of devolution appropriate to their own priorities. Ghana, India, Malaysia, Nigeria, the Sudan and Tanzania are among the nations in question, and it is with the third that this article is concerned. It is not suggested that the Malaysian experience is one to be emulated; rather that the structure now emerging has interesting implications, calling into question some orthodox reactions. $^{1}$

\footnotetext{
1 A full account of local government reform in Malaysia appears in the author's Local Government in Peninsular Malaysia, Saxon House. (forthcoming).
}

An important aspect of the Malaysian Reform, styled the 'restructuring' of local government, is the absence of consistent articulated objectives. In Nigeria, pressures for public participation following a prolonged period of military rule, for the distribution of newly acquired wealth, and for more autonomy within a large federal nation, so avoiding an excessive proliferation of states, have all contributed to the form of the new local governments. In Tanzania the restoration of the former urban authorities is presented as an appropriate reaction to a de-emphasis of urban needs established by earlier policies. Malaysia's reform in contrast appears as a compromise between conflicting reactions to what had become a discredited local government structure.

From the outset devolution is constrained by certain factors, notably by the perception of a Malay hegemony, which the Malay majority regard as indispensable to internal peace, and, associated with this, by the respect for state government sensitivity, especially in matters which are constitutionally of exclusive state concern. Neither is consistent with an elective, representative form of local government, at least so long as unbalanced ethnic population distribution creates localised Chinese majorities, frequently with opposition sympathies. The power and prestige of the federal and state public services deprive the third tier of scope and expectations of initiative. Notwithstanding, there exists a demand for representation, strongly voiced in the evidence collected for the Royal Commission in 1965-66, originating not merely from party ambitions, but from an association with values predominantly but not exclusively western. Indians, in particular the late Senator Athi Nahappan, Chairman of the Royal Commission, have been prominent spokesmen for elective democracy. Participation and involvement, though outside an elective system, was strongly urged by the late Premier Tun Razak shortly before his death, arising from his perception that the integrity of the Malaysian state could only be preserved on a foundation of public identification and commitment (speech to the National Seminar on Local Government, 30 June 1975). The relevance of local authorities as agencies to ensure a balanced distribution of public services, particularly in a rapidly developing nation with powerful single and multi-purpose public corporations, has been persistently pressed by the Ministry for Local 


\section{Government.}

As a compromise a system is emerging of considerable apparent promise, circumscribed by state control. Wide publicity has been given to the reform, exceeding the substance of current achievements. On one side the 1976 Local Government Act and Planning Legislation (Acts 171/76 and 172/76) have given local authorities the powers to be primary agents of government both in local planning and service provision, though excluding education and police. Local government is intended to cover all areas of Peninsular Malaysia, in marked contrast to the fragmented character of the earlier municipalities, town councils, town boards, and local councils. Yet by ensuring that all councillors are nominated by the state, and that most presidents or chairmen are civil servants, and by securing powers of state tutelage including abolition of unsatisfactory councils, democratic risk is avoided, if at the cost of reducing much of the popular appeal of the programme. The reform is accordingly treated by many critics as formalistic.

Yet recent developments should not be so readily dismissed. They are firstly a practical response, avoiding predictable local authority versus state conflict that destroyed the effectiveness of several of the earlier municipal and town authorities. Political exclusion of the opposition gives Federal and state governments an interest in promoting the reputation of their own nominees; local effectiveness reflects on the National Front Party.

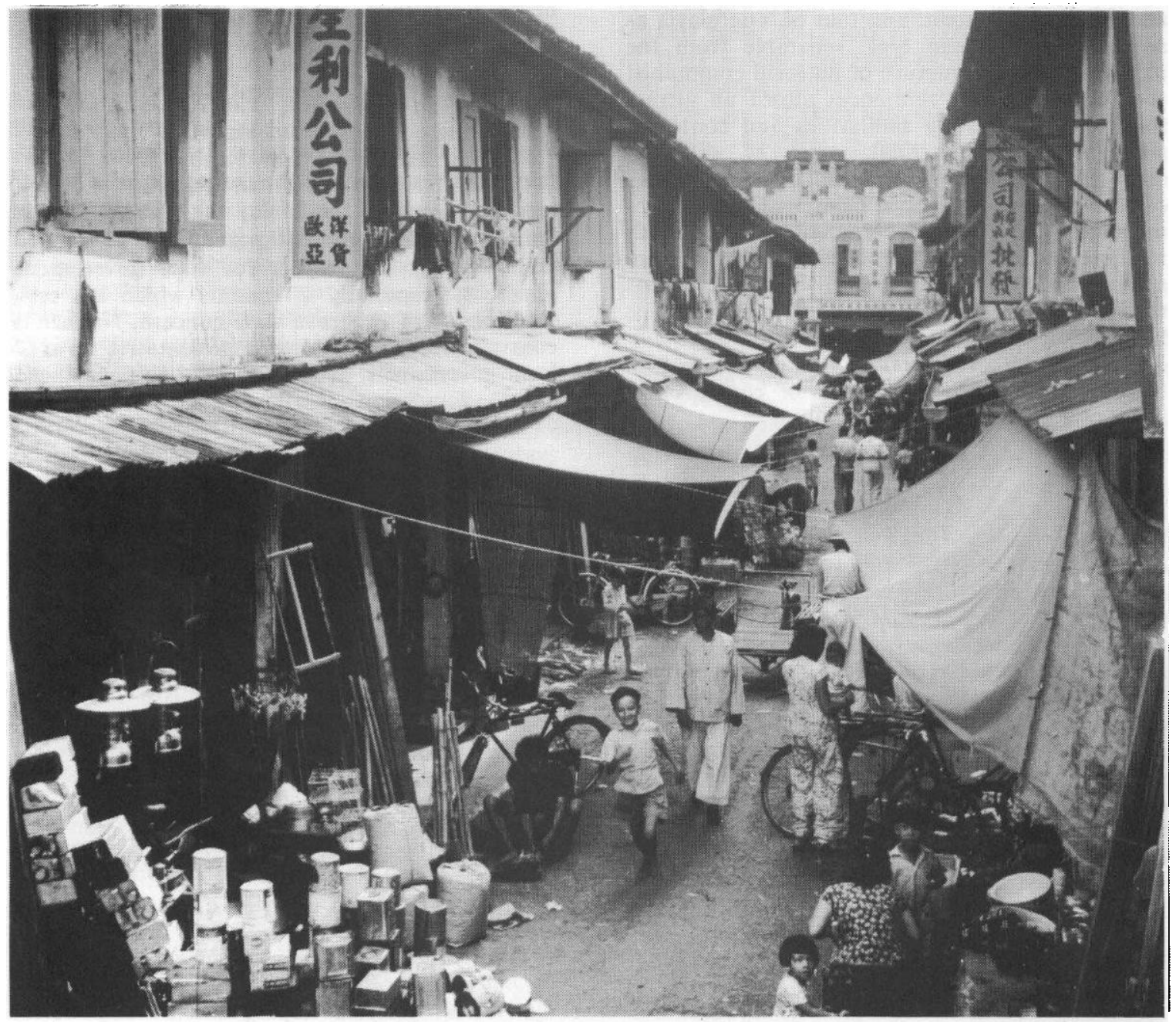

A street scene in Malacca, Western Malaysia.

Copyright: Shell I 
Experience so far does not indicate that the councils are necessarily passive. Penang Island is a case where many of the appointed councillors not only opposed the state over the Penang urban centre, but raised such severe criticism of the revaluation exercise as to drive the Chief Minister to hurried changes within the authority. ${ }^{2}$ The remedy lies in state hands, but is apparently no guarantee of compliance. Also the introduction in the councils of much stronger Malay representation, on the whole a more confident political element, is likely over the long term to ensure more effective demands on the higher tiers. The objection can be raised, as in some of the Johor district councils ${ }^{3}$ that genuine public representation is distorted in favour of a balance of interests between the components of the ruling party. While in principle this may not be democratic, in practice it is not necessarily disadvantageous to effective local pressure.

The appointment of civil servants as authority heads has positive as well as negative aspects. Experience has already shown that several have become strong advocates of their authorities, Seberang Perai being an excellent example. Published statements such as "with the potential that local authorities have in helping the people to achieve national aspiration both socially and economically, it will be a sad waste of a very efficient and effective link between the government and the people . . . if the government does not heed the call for help made by the local authorities" would hardly have been written had the civil servant concerned not been placed in a position of direct responsibility for the Council (Noh, 1977: 13). The traditional role of the district officer as supervisor has tended to confer a detached, superior and superficial acquaintance with local government affairs. This is no longer the case, as there is personal career interest in promoting the welfare of the authority. The public service pressure group can be effective, and is far more likely to be given a sympathetic hearing, as proved at Ipoh. This important municipality has an impressive history of effective local government, though in the past under the leadership of a regional opposition party and despite consequent local/state tension. Following the abolition of elected representation, a politician was nominated President. His deputy, however, was the former State Finance Officer, who in fact carried out a

\footnotetext{
2 Certain aspects of this corporation are described by Phang Siew Nooi (1978: 142-9).

3 Representations from the Chinese MCA Party, a component of the National Front, concerning the distribution in Kulai were published in The New Straits Times, 12 January 1976.
}

wide range of the President's functions. The marked improvement in communication, in the rapid processing of municipal applications, and in constructive reactions to requests was confirmed by senior officers experienced in the authority's affairs. The issue is whether in a particular stage of institutional development such appointments are not only the most politically acceptable, but are also in the long term interests of local authorities. The environment of the 1960 s with inadequate local revenues, weak support services, discrimination by other agencies and a general official neglect will not easily be tolerated.

Another major aspect of the reform, and one in which change is now far advanced, is that of areal reorganisation. The solution of a federally inspired blueprint, though offered by the Royal Commission on the basis of adopting the majority of district areas as authorities, has been rejected. In accord with the need to accommodate state priorities, each state has been encouraged to evolve its own solution according to broad guidelines, offered as advice by the Ministry for Local Government. Reactions have in consequence been mixed, ranging from an acceptance of the district structure in Selangor, to a partial district structure in Kedah, confined to those districts where financial and administrative viability seemed attainable on account of an existing populous centre, to at least a provisional rejection in Johor of several of the existing district boundaries in favour of new areas and the adoption by Penang of two authorities only, inspired by city-region concepts. As a consequence the new authorities have a surprising range and diversity of resources and capabilities.

Weaknesses in the new areas have been identified, notably the failure of authorities at this stage to deliver services, or to retain effective communication with areas far larger than in the past. Difficulties have predictably arisen, particuarly in Penang, involving the relations of district officers with appointed chairmen of authorities where boundaries do not coincide. It is too early to draw conclusions on the merits of the courses chosen, and diversity complicates the task of overall comparison and performance measurement at the federal level. On the other hand. given the fact that this is a period of experiment, there are arguments in favour of a number of contrasting solutions, the progress of which can be compared.

\footnotetext{
4 The authorities of Penang Island and Seberang Perai contain the extensive rural hinterlands of Georgetown and Butterworth respectively. The solution was discussed with foreign consultants in 1971 .
} 
Allowance is made for local demands and needs, and the state governments have not been faced with a fait-accompli. The contrast with recent Nigerian experience is very marked. It may be claimed that the more recent the reorganisation, the more seriously it has been examined, and the states have tried to take advantage of others' experience. Given the fact that areas are not static and that the ideal, if attainable at all, is only achieved at a particular time and for particular ends, the approach adopted has considerable merits. This may be asserted despite the slow application to their tasks adopted by several states, either from administrative inertia or an absence of financial resources to support any significant change.

Reference to finance focuses on a further major aspect of the reform, and in some respects its most defective. With irrefutable thoroughness the 1968 Commission drew attention to the parlous state of the then existing authorities, only four of which had any significant resources and accordingly a cadre of senior professional staff. All authorities depended on property rating and fees as their major local revenue sources, the former seriously constrained by the difficulties of revaluation, political interference-not infrequently from the state level ${ }^{5}$-and collecting from low value properties. The range of fees charged was limited by the narrow scope of the services provided. Grant aid was minimal, except in a few states such as Johor where significant balancing grants were given to the numerous local councils. The underlying principle accepted was that of 'financial autonomy', the capacity to support recurrent expenditure and debt charges with local revenues alone. The Royal Commission urged more efficient collection of sources, but in addition a more generous and rational approach to grant aid by the higher tiers. The subsequent Royal Commission under Justice Harun in 1974 emphasised a reduction in scope of services to accord with local resources, though supporting realistic financing of essential local services. The 1976 Act altogether rejected the latter approach, greatly enhancing expectations without significantly increasing the revenue base, at least in terms of available sources. Expectations of local government involvement in profitable enterprises are at best speculative.

An important aspect of areal restructuring was

5 As, for example, in Johor Bahru in 1971 following revaluation undertaken by the Valuation Division of the Treasury.

6 Apart from issues of internal competence, such activities overlap with. and indeed con Economic Development Corporations. the assurance by the Minister of additional aid to reformed authorities in terms of both launching and recurrent grants. Progress in implementing these benefits has been exceedingly slow despite two high level committees. Much discontent has inevitably followed. Property revaluation, though approached with courage in some towns, provoked an internal crisis in Penang Island, and has in practice secured only moderate gains in no way consistent with growing needs. Agreement on increased grants is at least being reached, though gradually and with marked lack of enthusiasm by the Treasury. In many states the Ministry is accused of having 'put the cart before the horse' in the restructuring process. This has been unquestionably the greatest weakness of the reforms, reducing the functional opportunities to illusion, and condemning the new councils to a dangerous period of public disappointment.

On the other hand it may be argued that the Malaysian experience, though neither planned nor, indeed, initially intended, is in some respects preferable to a conspicuously more generous approach. The traumatic experience of the Nigerian Local Governments, created with immense financial expectations, urged to ambitious capital programmes and the elimination of reserves, only to be faced with sudden and severe retrenchment has in no way been risked. Many of the new authorities have enjoyed little more than the merged resources of their component parts, notwithstanding far greater demands. Gains have been the reward of struggle both by the Ministry and the more articulate councils. The authorities have been compelled to apply themselves to revenue earning activities and the reduction of needless expenditure. Local government bodies as a whole have been led to increased interest in the technology of revenue earnings. The valuable seminar on property rating, seminar Kadaran at Kuala L u m p u r, 1977, is an example. Constraint is leading to incremental improvements, though in places quite significant as reflected in the increase of professional specialist staff at Butterworth, headquarters of the Seberang Perai Authority. Provided that the present demand continues to be rewarded, albeit slowly, the effect may prove rewarding over the medium term. As with other features of the reforms, aspects which appear dysfunctional may bring more beneficial consequences.

In no respect is this optimistic interpretation more justified than in the Ministry for Local Government itself. The office of the Commissioner of Local Government was. until 1968, staffed by the Commissioner himself, two clerks and an office boy. 
Criticised by the Harun Commission for the inadequacy of its resources (Government Printer, 1972 para. 112), the Ministry has been greatly reinforced by senior staff, some with considerable experience. Its approach has become active, promoting and holding seminars and conferences at national and state level, and establishing direct communications with the authorities in order to use its own limited funds to best effect. The progress of positive reforms owes a great deal to the efforts of Ministry officials, the effective survival of the Ministry itself depending on the vitality of the system it is intended to represent. A conclusion of limited success has to be judged against the strength of apathy to reform, found not only in the majority of the states, but in the major agencies of Federal Government. It is interesting that a Ministry can promote its own programme so effectively, in an environment where the Federal constitution precludes the creation of a strong Ministry with powers to direct the states.

It is appropriate, in conclusion, to return to the initial statement. No attempt has been made to discuss the qualities desired in a local government system. To some the present Malaysian structure is no more than a form of guided democracy, a pretence at devolution. The purpose of this appraisal is to suggest that reform in such a case is not directed to a clearly perceived end. It is a process creating its own opportunities, releasing forces in its evolution capable of influencing the course of its development and even of its longer term objectives. For the first time in its history Peninsular Malaysia has a nascent group of interrelated local authorities, protected by positive legislation, given widespread notice, and associated in their success with both the ruling party and elements in the civil service. Neither Federal nor state governments have cause to suspect the third tier, though they may prefer to ignore it. The situation is, at the least, interesting, more particularly for those in the throes of comparable compromise and uncertainty.

\section{References}

Government Printer, 1970, Report of the Royal Commission of Enquiry to Investigate into the Workings of Local Authorities in West Malaysia, Kuala Lumpur

Government Printer, 1972, Royal Commission on the Remuneration and Conditions of Service in Local Authorities and Statutory Authorities, Kuala Lumpur

Noh, Abdullah, 1977, in Local Government in Malaysia, National Echo

Phang Siew Nooi, 1978, Administration of Urban Redevelopment in Penang: the case of the Penang Urban Centre, M. Soc. Sc. Thesis, University of Malaya

\section{Erratum}

The IDS Bulletin, January 1979, vol. 10 no. 2, contained an article entitled "Appropriate Methodology: an Example Using a Traditional African Board Game to Measure Farmers' Attitudes and Environmental Images", in which reference was made to a modified version of the Mancala Board, called the Atteh board. The author would like to point out that this board was built by C. G. Knight and J. Flinn and has been extensively used by them in Nigeria. It was kindly made available by them for the work described in the paper. The author apologises for any misunderstanding which may have arisen from the nomenclature used in the article. 